\title{
Validation of anthropometric equations for predicting body mass and height in older women
}

\section{Validação de equações antropométricas para a predição da massa corporal' e estatura de mulheres idosas}

\author{
Gilberto Moreira Santos Júnior ${ }^{1}$ \\ (D) https://orcid.org/0000-0003-0962-2204 \\ Amandio Aristides Rihan Geraldes \\ (D) https://orcid.org/0000-0002-4222-2264 \\ Dante Wanderley Lima de Oliveira' \\ (iD) https://orcid.org/0000-0003-1419-3299 \\ Piettra Moura Galvão Pereira² \\ (iD) https://orcid.org/0000-0002-7278-2385 \\ Rodrigo B de Albuquerque ${ }^{1}$ \\ (D) https://orcid.org/0000-0001-6032-6166
}

\begin{abstract}
The main objective of the present study was to investigate the cross-validity of two of the most used foreign equations to predict the body mass (BM) and height (HEI) in Brasilian studies. Additionally, the importance of possible agreements or diferences between the observed and predicted independent variables (BM and HEI) have been verified. The BM and the HEI were measured with mechanical weighing Scale and portable stadiometer in a sample of 200 elderly women $(66,6 \pm 5,43$ years) living in Maceió city. To verify the validity of the regression equations, the folowing statistics were computed: Student T Test; Constant Error (CE); Total Error (TE) and Standard Error of Estimation (SEE). The agreement between the values: observed and predicted, were evaluated with Bland Altman test. The comparison between the observed and predicted values for BM and HEI showed significant and statistical diferences $(\mathrm{p}<0,05)$. Despite the fact that the CE, TE and SEE for the prediction of BM $(1,66$; $0,11 ; 6,33)$; HEI $(-0,02 ; 0,02 ; 0,10)$ and $\mathrm{BMI}(1,47 ; 0,10 ; 3,24)$ showed relatively close values (BM: 2,6\%; HEI: 1,31\%; BMI: 5,3\%), the differences between the results were statistically significant. The results suggest that, although relatively close, the values obtained through the equations observed in the study, should not be generalized to predict body mass and height of elderly women with similar characteristics to the sample used in the study.
\end{abstract}

Key words: Aging; Regression equation; Validation

Resumo - Oprincipal objetivo do presente estudo foi investigar a validade cruzada de duas equaçóes estrangeiras, amplamente utilizadas para predizer a massa corporal e a estatura de idosos em estudos brasileiros. Adicionalmente, investigou-se a importância das possiveis semelhanças ou diferenças entre o IMC observado e o predito. A massa corporal e a estatura, foram mensuradas com auxílio

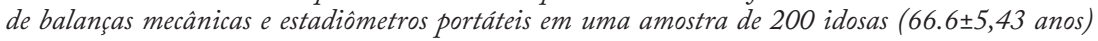
residentes em Maceió/AL - Brasil. Para verificar a validade das equações de regressão utilizou-se os seguintes recursos estatísticos: teste t de Student, erro constante (EC), erro total (ET) e erro padrão de estimativa (EPE). A concordância entre os valores estimados e preditos foi avaliada com auxilio do teste Bland-Altman. A comparação entre os valores de MC e EST obtidos através das equações $e$ os verificados na mensuração apresentaram diferenças estatisticamente significantes $s(p<0,05)$. $O$ $E C$ entre os valores preditos e medidos, os ET das equaçôes testadas, bem como, o EPE para a prediçâo das variáveis: $M C$ (EC: 1,66; ET: 0,11 e EPE: 6,33), EST (EC: -0,02; ET: 0,02 e EPE: 0,10) e IMC (EC: 1,47; EP: 0,10 e EPE: 3,24), embora os valores preditos e observados, pareçam relativamente próximos: 2,6\%,1,31\% e 5,3\%, respetivamente para $M C, E S T$ e IMC, as diferenças observadas foram estatisticamente significativas. Conclui-se que, em termos estatísticos, as equaçöes analisadas não devem ser utilizadas de maneira generalizada para a população de idosas brasileiras com características semelhantes às estudadas.

Palavras-chave: Envelhecimento; Equação de regressão; Validação
1 Federal University of Alagoas. Maceió, AL. Brazil

2 CESMAC University Center. Maceió, AL. Brazil

Received: October 02, 2020 Accepted: December 08, 2020

How to cite this article Santos Júnior GM, Geraldes AAR, Oliveira DWL, Pereira PMG, Albuquerque RB. Validation of anthropometric equations for predicting body mass and height in older women. Rev Bras Cineantropom Desempenho Hum 2021, 23:e77985. DOl: http://doi.org/10.1590/19800037.2021v23e77985

Copyright: This work is licensed under a Creative Commons Attribution 4.0 International License. 


\section{INTRODUCTION}

In 2018, the Brazilian population was estimated at 207.8 million people, including 21,872 million, the equivalent of $10.5 \%$, aged 65 years and over, which indicates that the Brazilian elderly population increased by $6 \%{ }^{1}$.

Given such change in the demographic profile, the concern of society with the health of the elderly population has increased, especially regarding problems related to morphological (body composition) and physiological changes, falls, especially nutritional deficits that may compromise the health and well-being of this age group ${ }^{2}$. Among previously described factors, nutritional status (NS) can be considered a determining variable for successful longevity'; so, it has been the subject of interest to the scientific community.

NS evaluation, in addition to being important for assessing the nutritional conditions of older adults, also helps professionals during nutritional and exercise prescription for people of all age groups, being part of health maintenance or improvement strategies ${ }^{4-6,}$, and drug dosage $\mathrm{e}^{7-9}$.

Several anthropometric measurements, such as body mass (BM), height (HEI), perimeters, skinfolds, bone lengths and diameters, among others, have been widely used for NS evaluation in epidemiological studies with the objective of prescribing diets, exercise or medication dosage $\mathrm{e}^{10,11}$. Regarding NS evaluation, Body Mass Index (BMI) obtained through the ratio between body mass and square height $\left(\mathrm{BMI}=\mathrm{BM} / \mathrm{HEI}^{2}\right)$ and expressed in $\mathrm{kg} / \mathrm{m}^{2}$, is the measure most widely used in epidemiological studies $^{3}$. However, under some conditions, such as lower limb amputations, the presence of disabling diseases, wheelchair use and bedridden patients, such measures are often impracticable or impossible.

Given the above, regression equations using different anthropometric measures as predictive variables, such as bone length, wingspan or half-wingspan and foot length have been often used, which are capable of predicting BM and HEI in the elderly population. In this context, since they use easy and accessible measurements (knee height $(\mathrm{KH})$, triceps (TSF) and subscapular (SSF) skinfolds and brachial (PBR) and leg perimeters (PPER), two equations, originally proposed by Chumlea et al. ${ }^{10,11}$, have been used in scientific studies to predict BM and HEI.

Interestingly, Monteiro et al. ${ }^{12}$ reported that although they were developed using a sample of Americans aged 65-104 years, without considering the influences of possible intervening variables such as ethnicity, genetics, cultural aspects and nutritional habits, among others, such equations have been widely used in Brazil and worldwide.

In addition to being scarce, studies investigating the validity of such equations in samples of Brazilian older women are inconclusive ${ }^{13}$. The above, associated with the approximation of values, due to possible HEI and BM errors, particularly in bedridden subjects, may lead to errors in dietary and exercise prescriptions, as well as in therapeutic planning ${ }^{4}$.

This study was conducted with the objective of evaluating the cross-val- 
idation of two equations ${ }^{10,11}$ widely used in national and international nutritional studies to predict BM and HEI in older women. Additionally, it was also intended to evaluate the importance of differences caused by the use of equations for BMI calculation.

\section{METHODS}

To compose the sample, 200 volunteers with minimum age of 60 years (60-86 years, $66.60 \pm 5.43$ years) were conveniently selected from a population of 800 women, participants of leisure physical activity programs offered by various institutions in the city of Maceió, who were functionally independent and without diagnosis of bone diseases, amputations or recent fractures, among other diseases that could interfere with performance in tests or that could be aggravated by the participation in the study.

The two equations evaluated proposed by Chumlea et al. ${ }^{10,11}$, are shown below:

$$
\begin{gathered}
\mathrm{HEI}=84.88+(1.83 \times \mathrm{KH})+(-0.24 \times \mathrm{Age}) \\
\mathrm{BM}=(0.98 \times \mathrm{PBR})+(1.27 \times \mathrm{PPER})+(0.4 \mathrm{XSSF})+(0.87 \mathrm{XKH})-62.35
\end{gathered}
$$

where: $\mathrm{KH}=$ knee height, $\mathrm{PBR}=$ arm perimeter, $\mathrm{PPER}=$ leg perimeter, $\mathrm{SSF}=$ subscapular skinfold.

All anthropometric measurements were performed according to recommendations proposed by Lohman et al. ${ }^{14}$.

Normality of distribution and homogeneity of data variances were respectively evaluated with the aid of Kolmogorov-Smirnov and Levene tests. To characterize the sample, central tendency measure (arithmetic mean) and dispersion measure (standard deviation) were used; amplitude was verified by the difference between maximum (MV) and minimum values $(\mathrm{mv})$ for each variable.

To verify the accuracy of Chumlea's equations based on cross-validation, paired student $t$, total error (TE), constant error (CE) and standard error of estimation (SEE) statistical tests were used. Additionally, the Bland-Altman test was used to evaluate the agreement between measured values and those estimated by equations proposed by Chumlea et al. ${ }^{10,11}$. For all tests, significance level of $\mathrm{p} \leq 0.05$ was adopted.

All study participants signed the free and informed consent form in accordance with recommendations of Resolution 466/12 of the National Health Council on research involving human subjects and approved by the ethics committee of the Federal University of Alagoas under protocol No. 23065.020769 / 2009 -30.

\section{RESULTS}

Values presented by the group of participants for age, BM, HEI and knee height $(\mathrm{KH})$ measures, as well as mean values obtained by prediction equations can be observed in table 1 . 
Table 1. Descriptive statistics for sample characterization $(n=200)$

\begin{tabular}{lcccc}
\hline & M & SD & vm & VM \\
\hline Age & 66.60 & 5.43 & 60.00 & 86.00 \\
Actual weight & 64.71 & 11.68 & 35.70 & 102.00 \\
Estimated weight & 63.04 & 12.55 & 16.51 & 95.76 \\
Actual height & 1.52 & .07 & 1.32 & 1.75 \\
Estimated height & 1.54 & .10 & 1.09 & 1.72 \\
Actual BMI & 27.90 & 4.79 & 15.87 & 45.33 \\
Estimated BMI & 26.42 & 5.04 & 7.46 & 43.44 \\
Knee height & 46.87 & 5.78 & 22.00 & 56.00 \\
\hline
\end{tabular}

Note. $\mathrm{Vm}=$ minimum value $; \mathrm{VM}=$ maximum value; $\mathrm{M}=$ mean; $\mathrm{SD}=$ standard deviation

To verify the predictive power of Chumlea's equations, cross-validation was performed using the following procedures, suggested by Lohman ${ }^{15}: 1$ ) comparison test between means (paired t-test) - observed means should not differ statistically; 2) calculation of the standard error of estimation (SEE) - aiming to indicate the expected margin of error in a prediction; 3) constant error (CE), representing differences between estimated and measured values; and 4) total error (TE) - indicating the size of the error associated with the number of subjects evaluated. Results can be seen in table 2 .

Table 2. Cross validation of Chumlea's equations ${ }^{10,11}$ for older women

\begin{tabular}{lccccc}
\hline & CE & TE & SEE & $t$ & $p$ \\
\hline BM & 1.66 & 0.11 & 6.33 & 2.57 & $<0.011$ \\
HEI & -0.02 & 0.02 & 0.10 & -3.08 & $<0.002^{*}$ \\
BMI & 1.47 & 0.10 & 3.34 & 4.84 & $0.000^{*}$ \\
\hline
\end{tabular}

Note. $\mathrm{t}=\mathrm{t}$ student, $\mathrm{p}=$ significance level; $\mathrm{CE}=$ constant error; $\mathrm{TE}=$ total error; $\mathrm{SEE}=$ standard error of estimation; ${ }^{*}$ significant difference $(p<0.05)$.

When compared, results showed BM $(1.66 \mathrm{~kg})$ and BMI underestimation $\left(1.47 \mathrm{~kg} / \mathrm{m}^{2}\right)$ and HEI overestimation $(0.02 \mathrm{~cm})$. Regarding predicted $\mathrm{HEI}$ and $\mathrm{BMI}$ values, significant statistical differences were found, although SEE values were below cutoff point proposed by Lohman ${ }^{15}$. In contrast, BM did not present statistically significant differences, although SEE of $6.33 \mathrm{~kg}$ does not meet validation criteria of the aforementioned author.

The analysis of the agreement between estimated and measured HEI, $\mathrm{BM}$ and BMI values (data not showed), verified using the method proposed by Altman and Bland, showed that the variable that presented the best agreement between measured and estimated values was HEI, which overestimated the actual measurement by only $0.02 \mathrm{~cm}$, while $\mathrm{BM}$ and BMI were underestimated by $1.66 \mathrm{~kg}$ and $1.47 \mathrm{~kg} / \mathrm{m}^{2}$ respectively.

Although the values found showed considerable agreement, since mean values were close to zero, especially HEI, graphs showed considerable dispersion between individual values. 


\section{DISCUSSION}

This study aimed to identify the cross-validity of two prediction equations proposed by Chumlea et al. ${ }^{10,11}$ to estimate BM and HEI in Brazilian older adults, since such equations are not only pioneer ${ }^{16}$, but also the most accepted and used in Brazil and in most western countries 9 .

The proposed equations use knee height as one of the main alternatives, justified by the fact that it does not change with advancing age. Additionally, it is discussed how possible differences between the two measures could affect BMI results, since this measure is the most used in epidemiological studies investigating NS.

Objectively, the observed results showed significant differences $(\mathrm{p}$ $<0.001$ ) between actual and predicted measurements for all anthropometric variables, except for BM. These results overestimate measured values by $1.66 \mathrm{~kg}$ for $\mathrm{BM}$ and $0.02 \mathrm{~cm}$ for HEI. As a result of these differences, BMI was also overestimated by $1.47 \mathrm{~kg} / \mathrm{m}^{2}$.

Standard error values observed were low for HEI $(\mathrm{SEE}=0.10 \mathrm{~cm})$ and $\mathrm{BMI}(\mathrm{SEE}=3.34)$ although they were high for $\mathrm{BM}(\mathrm{SEE}=6.33 \mathrm{~kg})$, according to $\mathrm{Lohman}^{16}$, who established cutoff point for $\mathrm{SEE}$ of $\leq 3.5$. It is important to highlight that in relation to SEE, the proposed cutoff point is appropriate for equations developed with the use of skinfolds among independent variables, which reinforces the inadequacy of formulas to predict BM and HEI proposed by Chumlea, as they present SEE above the proposed cutoff point.

The results found differ from other studies, such as Closs et al. ${ }^{17}$, which showed that knee height may be a reliable alternative measure in the nutritional assessment of older adults. Using sample composed of 186 individuals (74.3 \pm 7.1 years), the author found positive correlation between measured height and height estimated by Chumlea's equation, although the predicted result overestimated the actual measurement by $3 \mathrm{~cm}$. Likewise, Muncie et al. ${ }^{18}$ evaluated the validity of the Chumlea's equation for predicting HEI in a sample of 19 hospitalized white and black older women (78 \pm 6 years) and although it was observed that predicted results underestimated actual results by about $4 \mathrm{~cm}$, the results pointed out that the Chumlea's equation presented good predictive value, showing no statistical differences in relation to actual height. In turn, our study showed underestimation much closer to the actual value $(0.02 \mathrm{~cm})$, but the results showed significant statistical differences. However, it is necessary to consider that, regarding the height variable, prediction errors found in studies by Closs et al. ${ }^{17}$ and Muncie et al. ${ }^{18}$ and in our study are within cutoff point proposed by Beghetto et al. ${ }^{19}$, which considers $5 \mathrm{~cm}$ an acceptable error margin.

On the other hand, Myers et al. ${ }^{20}$ investigated the suitability of the same HEI prediction equation used in our study in 16 men ( $72 \pm 7.4$ years) and 16 women (72 \pm 8.7 years) of Japanese descent and found that the equation overestimated HEI for women by $1.5( \pm 0.64 \mathrm{~cm})$, which results were not statistically significant. Although values are very close to those 
found in this study, ethnic and age differences between samples, as well as the quite different physical conditions between samples seem to explain the significant differences found.

Similarly, Berger et al. ${ }^{8}$ using 250 subjects aged 16-89 years (61.4 \pm 15.2 years), tested the validity of the Chumlea's equation ${ }^{11}$ for HEI and found significant differences when compared to direct measurements, overestimating actual values by five and seven centimeters. It is noteworthy that the age groups used in samples were very different and in addition to not reporting the ethnicity of subjects, individuals were physically very fragile, which may explain differences found, since the long time required for measurements, as well as the need for great effort and help in obtaining them can lead to significant measurement errors ${ }^{21}$.

A study by Rabito et al. ${ }^{7}$ conducted on hospitalized Brazilians of both sexes ( $49 \pm 17$ years) tested some equations proposed by Chumlea for HEI and BM and among them those used in our study, which showed statistically significant differences ( $p>0.05$ ). For both HEI and BM, the distinct ethnic characteristics between samples, according to the author, may have been responsible for differences found, although in our study, also with Brazilians (not hospitalized), measured and estimated values were closer, contrary to the justification of that study. It is important to highlight that the ethnicity factor, according to Freire ${ }^{22}$, should not be considered in Brazil, as its intense miscegenation makes it difficult to establish any racial pattern with minimal security.

Oliveira and Filho ${ }^{4}$ validated Chumlea et al. ${ }^{10,11}$ equations for the prediction of BM and HEI in a sample of 30 physically active women (66.6 \pm 6.68 years) from the state of Paraíba, northeastern Brazil. Unlike our results, the authors found no significant difference between measured and estimated BM and HEI, although HEI and BM were both underestimated (2.38 $\mathrm{cm}$ and $1.92 \mathrm{~kg}$ respectively). However, according to Filho ${ }^{23}$, the small sample $(\mathrm{n}=30)$ and the large data dispersion (evidenced by the high standard deviation) may contribute to estimation errors such as those found in the above study. Despite the clear validation, the authors only verified differences between averages of actual and predicted values using the t-test, which for many authors, is insufficient to validate any prediction method. Similarly, Galisa and Pustiglione ${ }^{24}$ validated the Chumlea's equation for HEI in 50 hospitalized Brazilian women, demonstrating strong correlation between actual and estimated measurements. In that study, the sample size may have significantly contributed to results found.

According to Chumlea et $a 1 .{ }^{25}$, the fact that HEI was significantly overestimated seems to be somewhat predicted, and therefore height estimates should be used primarily over direct measurements, since directly measured HEI does not reflect the exact HEI of older adults undergoing physical changes as a result of advancing age. Sampaio et al. ${ }^{26}$ reinforces this statement arguing that estimated HEI seems to be more compatible with the height of the individual in adulthood. However, one of the reasons that led us to question the validity of this equation was that some studies, 
contrary to statements above, found HEI underestimation ${ }^{27}$.

With regard to body mass, Bernal-Orozco et al. ${ }^{9}$ were unable to validate the Chumlea et al. ${ }^{10}$ equation in a sample of 95 Mexican older women. In that study, values obtained compared to directly measured BM showed differences of - 3.7 and $-6.6 \mathrm{Kg}$, underestimating values, similarly to our results. It is important to note that the sample of this study was composed of hospitalized and / or institutionalized older women, which may have influenced BM underestimation, since Chumlea's equations were obtained from physically active older adults. In a study with 209 adult and older adult patients of both sexes from the city of Fortaleza, Sampaio et al. ${ }^{26}$ demonstrated that the equations proposed by Chumlea showed good correlation with direct measurements, both in adults and older adults, although with differences in averages obtained, underestimating BM by $1.34 \mathrm{~kg}$, which result are very close to those of this study.

Similarly, a study conducted with a population of hospitalized older adults ( $>65$ years) of both sexes in Barcelona-Spain ${ }^{27}$, whose ethnicity was not reported, tested the validity of Chumlea's equations for BM, and although finding statistically significant correlations between actual and estimated weight, demonstrated that Chumlea's equations underestimated the actual values of all variables analyzed ( $\mathrm{p}<0.001)$. The study reinforced the need for the development of specific equations for the estimation of variables analyzed.

In hospitalized or institutionalized older patients, BM tends to be underestimated, especially in women, since in this age group, there is a decline in lean body mass, as well as an inversion in body fat distribution from limbs to the abdominal region, influencing estimated weight validity, since these formulas use arm and calf circumference and subscapular skinfold, and in obese individuals, these errors seem to be greater ${ }^{28}$.

In fact, variations in BM values may reflect relevant nutritional imbalances and may characterize fragility or adverse health effects such as disease aggravation, hospitalization and death ${ }^{6}$. Inadequate BM estimates may lead to the use of drug and diet therapies that do not meet actual individual or collective needs. In physical exercise programs for the elderly population, reliable BM and HEI data are required for adequate and individualized prescription ${ }^{4}$. Therefore, BM is an important tool for the early identification of older individuals at nutritional risk, thus improving the quality of care $^{9}$. In this sense, other studies conducted to verify the applicability of Chumlea's equations in a population of hospitalized / institutionalized older adults in Brazil ${ }^{6,15,28}$ could not confirm the validity of these equations.

Consequently, prediction errors in HEI and BM measurements generate inaccuracy in BMI, leading to possible calculation errors for nutritional supply with consequent impairment in the recovery of hospitalized older patients $^{27}$. Therefore, its use is controversial, especially in the elderly, due to the decrease in height, adipose tissue accumulation, reduction in muscle mass and in the amount of body water ${ }^{3}$.

Our results demonstrate BMI underestimation $\left(1.47 \mathrm{~kg} / \mathrm{m}^{2}\right)$ when predicted and overestimated HEI and predicted and underestimated BM 
were used. Similarly, Fogal et al. ${ }^{16}$ found BMI underestimation in older women $\left(0.9 \mathrm{~kg} / \mathrm{m}^{2}\right)$ when overestimated EST was used. The same underestimation was found by Salgado et al. ${ }^{27}$ using underestimated HEI and BM to calculate BMI. Similar BMI underestimation results were found in other studies ${ }^{17,26}$. It is important to note that the equations proposed by Chumlea considered in this study were developed from physically active older adults, which can maximize HEI overestimation in less healthy individuals and consequent underestimate BMI; however, considering more homogeneous and specific samples of each population avoids major nutritional assessment errors while promoting health gains.

The divergent results found between above studies and our study allow us observing that the aging process acts individually in people of different ethnicities ${ }^{5}$, also considering possible anatomical differences. Considering that both HEI and BM are important variables for assessing nutritional status and, especially drug dosing, specific prediction equations for these measures should be developed for older adults, especially Brazilians, taking into account gender, age and ethnic miscegenation. It is equally important that predictive models should present partial significance of variables, lower standard error of estimate (SEE), higher multiple correlation coefficient $\left(\mathrm{r}^{2}\right)$, model practicality and fewer independent variables ${ }^{16}$.

From the statistical point of view, the fact that studies did not analyze the standard error of estimation established by Lohman ${ }^{15}$ as one of the main validation techniques of new equations may explain the different results found in the main studies. Moreover, differences in ethnicities, age groups, cultural aspects and physical conditions verified in the different studies may contribute to the discrepancy found between actual and estimated measurements.

Studies using anthropometric measurements should be interpreted with caution. According to Sullivan et al. ${ }^{28}$, to avoid erroneous conclusions, the reliability of the measurement technique should be considered, even when using experienced evaluators, since reproducibility varies considerably, being able to transfer to prediction equations measurement errors that can theoretically be sources of prediction errors. Careful attention should be paid to measurement procedures; otherwise, the results obtained could be totally useless for analysis purposes. This becomes relevant, since many validation studies do not declare the reproducibility of anthropometric measurements used ${ }^{29,30}$.

\section{CONCLUSION}

The analyzed equations could not be used in a general way for the Brazilian elderly population, at least with regard subjects with characteristics similar to those of this study. In this sense, further studies should be carried out with the objective of constructing specific equations capable of predicting valid $\mathrm{BM}, \mathrm{HEI}$ and $\mathrm{BMI}$ results for the hospitalized elderly Brazilian population, especially the most fragile ones. 


\section{COMPLIANCE WITH ETHICAL STANDARDS}

\section{Funding}

This research did not receive any specific grant from funding agencies in the public, commercial, or non-profit sectors. This study was funded by the authors

\section{Ethical approval}

Ethical approval was obtained from the local Human Research Ethics Committee - Research Ethics Committee of the Federal University of Alagoas: Protocol No. 23065.020769 / 2009 -30, and it was written in accordance with standards set by the Declaration of Helsinki.

\section{Conflict of interest statement}

The authors have no conflict of interests to declare.

\section{Author Contributions}

Conceived and designed experiments: A.A.R.G; G.M.S.J. Performed experiments: G.M.S.J; R.B.A; D.W.L.O; P.M.G.P. Analyzed data: A.A.R.G; G.M.S.J. Contributed with reagents/materials/analysis tools: A.A.R.G; G.M.S.J. Wrote the paper: G.M.S.J.

\section{REFERENCES}

1. Brasil. Instituto Brasileiro de Geografia e Estatística. Pesquisa Nacional por amostra de domicílios continua. 2a ed. Rio de Janeiro, 2018.

2. Sampaio LR. Avaliação Nutricional e envelhecimento. Rev. Nutr.2004; 507-514.

3. Souza R, Fraga JS, Gottschall CBA, Busnello FM, Rabito EI. Avaliação antropométrica em idosos: estimativas de peso e altura e concordância entre classificações de IMC. Rev Bras Geriatr Gerontol 2013; 16(1): 81-90.

4. Oliveira LD, Filho JF. Estatura e massa corporal mensurados e preditos através das equações de chumlea em idosas. Fit Perf J 2007; 152-155.

5. Guerra RS, Fonseca I, Pichel F, Restivo MT, Amaral TF. Hand Length as an alternative measurement of height. Eur J Clin Nutr 2014;68(2):229-33.

6. Lima MFS, Cabral NLA, Oliveira LP, Liberalino LCP, Spyrides MHC, Lima KC, Lyra CO. Estimativa de peso em idosos institucionalizados: qual equação utilizar?. Rev Bras Epidemiol 2016; 19(1): 135-148.

7. Rabito EI, Vannucchi GB, Suen VM, Neto LL, Marchini JS. Weight and height prediction of immobilized Patients. Rev Nutr 2006; 655-661.

8. Berger MM, Cayeux MC, Schaller, MD, Soguel L, Piazza G, Chioléro RL. Stature estimation using the Knee height determination in critically ill patients. E Spen Eur E J Clin Nutr Metab 2008; 3(2): e84-e88.

9. Bernal-Orozco MF, Vizmanos B, Hunot C, flores-Castro M, Leal-Mora D, Cells A., et al. Equation to estimate body weight in elderly mexican women using anthropometric measurements. Nutr Hosp 2010; 25(4):648-655.

10. Chumlea WC, Guo S, Roche AF, Steinbaugh ML. Prediction of body weight for the nonambulatory elderly from anthropometry. J Am Diet Assoc 1988; 88(5): 564-568.

11. Chumlea WC, Roche AF, Steinbaugh ML. Estimating stature from knee height for persons 60 to 90 years of age. J Am Geriatr Soc1985; 33(2):116-120. 
12. Monteiro RS, Cunha TR, Santos ME, Mendonça SS. Estimativa de peso, altura e índice de massa corporal em adultos e idosos americanos: revisão. Com Ciênc Saúde 2009;20(4): 341-350.

13. Rezende FA, Rosado LE, Franceschinni SD., Rosado GP, Ribeiro RD. Avaliação da aplicabilidade de fórmulas preditivas de peso e estatura em homens adultos. Rev Nutr 2009;22(4):443-451.

14. Lohman TG, Roche F, Martorell R. Anthropometric standardization Manual Illinois: Kinetics Books; (1988).

15. Lohman TG. Advances in body composition assessment.Human Kinetics. 1992.

16. Fogal AS, Franceschini SCC, Priore SE, Cotta RMM, Ribeiro AQ. Stature estimation using the Knee Height measurement amongst Brazilian elderly. Nutr Hosp 2015;31(2):829-834.

17. Closs VE, Feoli AMP, Schwanke CLA. Altura de joelho como medida alternative confiável na avaliação nutricional de idosos. Rev Nutr 2015;28(5):475-484.

18. Muncie HE, Sobal J, Hoopes M, Tenney JH, Warren JW. A Pratical method of estimating stature of bedridden female nursing home patientes. J Am Geriatr Soc 1987;35(4):285-9.

19. Beghetto MG, Fink J, Luft VC, de Mello ED. Estimates of body height in adult inpatients. Clin Nutr 2006;25(3):438-43.

20. Myers SA, Takiguchi S, Yu M. Stature estimated from knee height in elderly Japanese Americans. J Am Geriatr Soc 1994;42(2):157-60.

21. Hickson M, Frost G. A comparison of three methods for estimating height in the acutely ill elderly population. J Hum Nutr Diet 2003;16(1):13-20..

22. Freire JJB. Estatura: dado fundamental em Antropologia Forense. Faculdade de Odontologia de Piracicaba. 2000.

23. Filho UD. Introdução à estatística para simples mortais. Negócio Editora. 1999.

24. Galisa MS, Pustiglione M. Critérios de avaliação antropométrica em geriatria - um estudo comparativo. Mundo Saúde. 1997;21(4): 199-203.

25. Chumlea WC, Roche AF,Mukherjje D. Some anthropometric indices of body composition for elderly adults. J Gerontol 1986; 41(1): 36-39.

26. Sampaio HAC, Melo MLP, Almeida PC, Benevides ABP. Aplicabilidade das fórmulas de estimativa de peso e altura para idosos e adultos. Rev Bras Nutr Clin 2002; 17(4): 117-121.

27. Salgado MC, Souza MFC, Pires CL, Souza MKB, Santos KPC, Santos KR, et al. Precisão das equações preditivas de peso corporal e altura: Proposta de um percentual de ajuste. Braspen J 2017; 32(4): 347-52.

28. Barceló M, Torres O, Mascaró J, Francia E, Cardona D, Ruiz D. Assessing nutritional status in the elderly; evaluation of Chumlea's equations for weight. Nutr Hosp 2013;28:314-318.

29. Sullivan DH, Patch GA, Baden AL, Lipschitz DA. An approach to assessing the reliability of anthropometrics in elderly patients. J Am Geriatr Soc 1989;37(7):60713.

30. Melo APF, Salles RK, Vieira FGK, Ferreira MG. Métodos de estimativa de peso corporal e altura em adultos hospitalizados: uma análise comparativa. Rev Bras Cineantropom Desempenho Human 2014; 16(4): 475-484

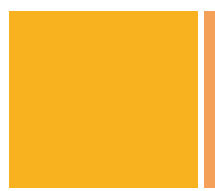

Corresponding author

Gilberto Moreira Santos Júnior

Rua Cônego Fernando Lira, 274, Trapiche da Barra, Maceió,

Alagoas, AL, Brasil. 57010-430.

Email: moreirasjr@hotmail.com 